\title{
Optimization of PCR conditions to detect susceptibility genes, KCNQ1, TCF7L2, and DPP4, for type 2 diabetes mellitus in Filipinos
}

\author{
Ruffa Mae Cadiz ${ }^{1}$, Micah Kesiya Manalo ${ }^{1}$, Andrea G. Vargas ${ }^{1}, \mathcal{E}_{\text {Librado A. Santiago }}^{1,2,3 *}$ \\ ${ }^{1}$ Department of Biochemistry, Faculty of Pharmacy, ${ }^{2}$ Research Center for the Natural and Applied \\ Sciences, ${ }^{3}$ The Graduate School, University of Santo Tomas, 1015 Manila, Philippines
}

\begin{abstract}
Type 2 diabetes mellitus (T2DM) is a chronic disease that is increasing at an alarming rate in Asian countries including the Philippines. The aim of this study is to optimize PCR conditions to detect SNPs within the susceptibility genes KCNQ1, TCF7L2, and DPP4 and to verify if mutations within these genes are targeted. PCR conditions were optimized for each of the genes using gene specific primers. These conditions were then used to detect single nucleotide polymorphisms (SNPs) in each of the susceptibility genes of the selected samples. Gene specific primers were designed based on the translated regions of the target genes. For TCF7L2, F/R (GGCTTTCTCTGCCTCAAAACC/ACTAAGGGTGCCTCATACGG); for DPP4 - F/R (CCCAGGTTCGCTGACAAATC/TCATTCCACGGTTGCAGGTG) and for KCNQ1- F/R (GTAAGCAGATGACAGGGCAGT /TAAAGGTCCT GACCCCCACC). Template DNA was obtained from patients of the University of Santo Tomas Hospital (USTH). The final concentration of the PCR components are: 1X 2X Taq Master Mix, $10 \mu \mathrm{M}$ forward and reverse primers, and 2ng DNA template. For the PCR conditions: initial denaturation, $3 \mathrm{~min}$; 35 cycle of denaturation, $1 \mathrm{~min}$, annealing, $1 \mathrm{~min}$, elongation, $1 \mathrm{~min}$ and; final elongation of $5 \mathrm{~min}$. The annealing temperatures were optimized at $58.3^{\circ} \mathrm{C}$ for $K C N Q 1$ and $54.5^{\circ} \mathrm{C}$ for $T C F 7 \mathrm{~L} 2$. The genes were successfully amplified giving the correct fragment lengths. The designed primers and PCR conditions for KCNQ1 and TCF7L2 were effectively used to verify the SNPs within the susceptibility genes.
\end{abstract}

Keywords: T2DM, PCR, SNPs, primers, KCNQ1, TCF7L2, DPP4

\section{INTRODUCTION}

Type 2 diabetes mellitus (T2DM) is a serious metabolic disease associated with an increased risk of premature death and substantial disability, largely mediated through its adverse effects on the vasculature. The prevalence of the disease *To whom correspondence should be addressed:
santiagolibrado@yahoo.com is increasing, and the World Health Organization estimates suggest that by 2025 there will be 300 million affected individuals worldwide [1].

The disorder is characterized by a combination of impaired insulin secretion and insulin action, both of which precede and predict the onset of disease [2]. In recent years, molecular approaches have been used in the diagnosis and prediction of susceptibility to diseases such 
as in the different forms of cancers, chronic obstructive pulmonary as well as T2DM. Single nucleotide polymorphisms (SNPs) is one such approach for which candidate genes have been strongly associated in disease occurrence in various races and populations. SNPs occur normally throughout a person's DNA, once in every 300 nucleotides on average. They are utilized as genetic markers, helping scientists locate genes that are associated with disease [3].

The use of polymerase chain reaction (PCR) and its downstream applications were employed to detect the presence of candidate genes in order to establish the association with T2DM. Association studies using the genes, DPP4, KCNQ1 and TCF7L2 have already been strongly implicated with increased risk of T2DM in Malaysian, Chinese, and Japanese individuals $[8,15,17]$. In this study, the detection of these genes in Filipino diabetic and non-diabetic patients is optimized.

Dipeptidyl peptidase 4 (DPP4), which is also known as CD26, is a ubiquitously expressed glycoprotein of $110 \mathrm{kDa}$, which was first characterized by Hopsu-Havu and Glenner [4]. The human DPP4 gene is located on chromosome 2, spans $70 \mathrm{~kb}$, and consists of 26 exons. The importance of $D P P 4$ for the scientific and medical community raised substantially since the approval of DPP4 inhibitors for the treatment of T2DM [5].

The transcription factor-7-like-2 (TCF7L2) gene encodes the transcription factor 4 (TCF4) which is involved in Wnt signaling. In the nucleus, stabilized $\beta$-catenin binds to TCF transcription factors to regulate the transcription of Wnt target genes. The $\mathrm{Wnt} / \beta$-catenin signaling pathway affects pancreatic $\beta$-cell development and function, and thus affects glucose metabolism. TCF7L2 gene has been consistently associated with type 2 diabetes mellitus (T2D) in different ethnic groups [6].
Potassium voltage-gated channel subgamily Q member 1 (KCNQ1) gene has a total of 17 exons, spans $404 \mathrm{~kb}$ of chromosome sequence and is located on chromosome 11p15.5. It encodes a pore-forming subunit of a voltage- gated $\mathrm{K}+$ channel (KvLQT1) and salt transport in epithelial tissues. KCNQ1 was reported to be expressed in insulin-secreting cells and inhibition of this potassium channel has been shown to significantly increase insulin secretion [7].

The study, therefore, aims to optimize PCR conditions in the detection of the susceptibility genes KCNQ1, TCF7L2, and DPP4 to establish their association with the development of T2DM.

\section{EXPERIMENTAL}

Samples and DNA extraction. DNA of whole blood samples was obtained from three diabetic and three nondiabetic patients of the USTH. The protocol was approved by the Faculty of Pharmacy Ethics Review Committee. Total genomic DNA was extracted using the Vivantis (Malaysia) GF-1 Blood DNA Extraction Kit and the DNA were kept at $-20^{\circ} \mathrm{C}$ for storage.

Oligonucleotide primers. Primers were designed based on the translated regions of the target genes. The designed primers were synthesized by Integrated DNA Technologies, Singapore. The primer pairs Forward/Reverse (F/R) for each gene are as follows: For TCF7L2, F/ R(GGCTTTCTCTGC C TCAAAACC/ ACTAAGGGTGCCTCATACGG); for DPP4 - F/ R (CCCAGGTTCGCTGACAAATC/ TCATTCCACGGTTGCAGGTG) and for KCNQ1$\mathrm{F} / \mathrm{R}$ (GTAAGCAGATGACAGGGCAGT / TAAAGGTCCTGACCCCCACC).

Polymerase chain reaction. PCR was carried out based on manufacturer's recommendation (Vivantis, Malaysia), using gradient PCR in BioRad thermal cycler with DNA Template 
concentration, $0.02-5 \mathrm{mg}$; primer concentration, 0.1-1.0 $\mu \mathrm{M}$ and; 2X Taq Master Mix concentration (1X). The primer concentrations used in PCR were optimized to $10 \mathrm{mM}$. The concentration of the $2 \mathrm{X}$ Taq master mix was kept constant. The DNA template concentrations used in the PCRs were optimized to 4ng per reaction. To obtain the optimum annealing temperature for each primer pair, gradient PCR was used as listed in Table 1.

Agarose gel electrophoresis. A Vivantis VC 100bp Plus DNA Ladder (Malaysia) was used and $3 \%$ agarose gel electrophoresis was run at 100 volts for $30 \mathrm{~min}$. The gel was placed in a UV tray and viewed using Gel Doc Ez imager (California).

DNA purification and sequence analysis. PCR products of successful amplifications were sent to First Base Sdn. Bhd., Malaysia for DNA sequencing after purification using the Vivantis Purification Kit GF-1 Ambiclean Kit (Malaysia). The sequences were analyzed using the Basic Local Alignment Search Tool BLAST (https:// blast.ncbi.nlm.nih.gov/Blast.cgi).

\section{RESULTS AND DISCUSSION}

Selection of target genes and SNP loci. Studies (Table 2) show that different races and populations have single nucleotide variation found strongly associated with T2DM. The choice for target genes and SNP loci (from $\mathrm{dbSNP}$ ) were based on the strongest association

Table 1. Gradient PCR

\begin{tabular}{l|c|c}
\hline \multicolumn{1}{c|}{ PCR Conditions } & $\begin{array}{c}\text { Temperature } \\
\text { (9) }\end{array}$ & Time \\
\hline Initial denaturation & $94^{\circ} \mathrm{C}$ & $2 \mathrm{~min}$ \\
\hline Cycles: 35 & & \\
\hline Denaturation & $94^{\circ} \mathrm{C}$ & $2 \mathrm{sec}$ \\
Annealing & $45,50,55,60^{\circ} \mathrm{C}$ & $1 \mathrm{~min}$ \\
Elongation & $72^{\circ} \mathrm{C}$ & $30 \mathrm{sec}$ \\
\hline Final extension & $72^{\circ} \mathrm{C}$ & $7 \mathrm{~min}$ \\
\hline & $4.0^{\circ} \mathrm{C}$ & $\infty$ \\
\hline
\end{tabular}

studies: for KCNQ1, A/G in rs2237895 [12]; for TCF7L2, C/T in rs7903146 [17] and; for DPP4, $\mathrm{A} / \mathrm{G}$ in rs4664443 [8].

Primer design. Primers for each of the T2DM susceptibility genes were designed based on the published sequences of the genes, considering the SNP loci from the SNP database. For KCNQ1, forward primer: 5'GTAAGCAGATGACAGGGCAGT-3', reverse primer: 5'-TAAAGGTCCTGACCCCCACC-3', with a product length of 188bp. For TCF7L2, forward primer: 5'GGCTTTCTCTGCCTCAAAACC-3', reverse primer: 5'-ACTAAGGGTGCCTCATACGG-3', with a product length of 109bp. For DPP4, forward: 5'-CCCAGGTTCGCTGACAAATC-3', reverse primer: 5'TCATTCCACGGTTGCAGGTG-3' with a product length of 133bp. Primers were verified using BLAST (https://blast.ncbi.nlm.nih.gov/ Blast.cgi).

BLASTn. The primer sequences subjected to the BLASTn, showed degree of alignment and complementarity of primers with target genes primarily in homo sapiens and other species as shown Fig. 1.

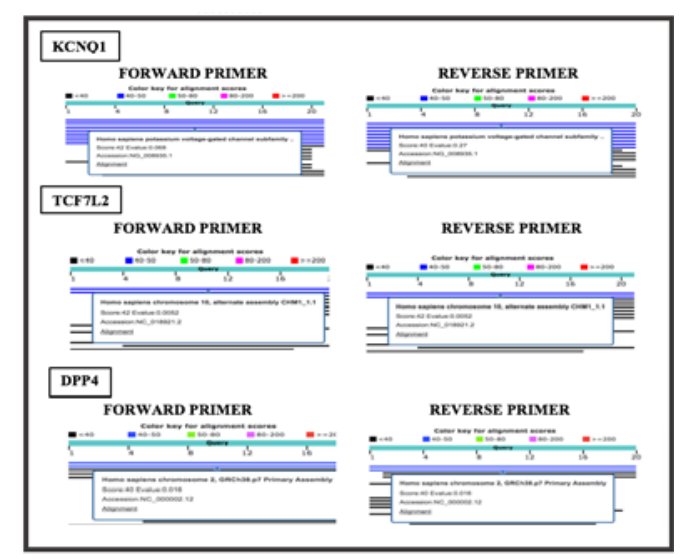

Figure 1. BLASTn 
Table 2. Reference SNP for candidate genes associated with T2DM

\begin{tabular}{|c|c|c|c|c|c|c|}
\hline Nationality & Gene & Chromosome & dbSNP & Location & Allele & Reference \\
\hline Malaysia & DPP4 & 2 & $\begin{array}{c}\text { rs12617656 } \\
\text { rs4664443 } \\
\text { rs7633162 } \\
\end{array}$ & 45,164 & $A>G$ & {$[10]$} \\
\hline China & DPP4 & 2 & $\begin{array}{l}\text { rs4664443 } \\
\text { rs3788979 } \\
\text { rs7608798 } \\
\text { rs1558957 } \\
\end{array}$ & 45,164 & $A>G$ & [11] \\
\hline China & KCNQ1 & 11 & $\begin{array}{l}\text { rs2074196 } \\
\text { rs2237892 } \\
\text { rs2237895 } \\
\text { rs2237897 }\end{array}$ & 390,974 & $A>C$ & [12] \\
\hline China & KCNQ1 & - & rs151290 & & & [13] \\
\hline Malaysia-China & KCNQ1 & 11 & $\begin{array}{l}\text { rs2237892 } \\
\text { rs2283228 } \\
\text { rs2237895 }\end{array}$ & 390,974 & $A>C$ & [14] \\
\hline East Asia and Europe & KCNQ1 & 11 & $\begin{array}{l}\text { rs2283228 } \\
\text { rs2237895 } \\
\text { rs2237897 } \\
\end{array}$ & 390,974 & $A>C$ & [15] \\
\hline Korea & KCNQ1 & - & $\begin{array}{c}\text { rs1111875 } \\
\text { rs2237892 } \\
\text { rs13266634 }\end{array}$ & & & {$[16]$} \\
\hline China & KCNQ1 & 11 & $\begin{array}{l}\text { rs2237892 } \\
\text { rs2237895 } \\
\text { rs2237897 } \\
\end{array}$ & 390,974 & $A>C$ & [17] \\
\hline China & KCNQ1 & 11 & $\begin{array}{l}\text { rs2237892 } \\
\text { rs2237895 }\end{array}$ & 390,974 & $A>C$ & [18] \\
\hline Japan & TCF7L2 & 10 & $\begin{array}{c}\text { rs12255372 } \\
\text { rs7903146 } \\
\text { rs7901695 } \\
\text { rs11196205 }\end{array}$ & 48,372 & $\mathrm{C}>\mathrm{T}$ & [19] \\
\hline China & TCF7L2 & 10 & $\begin{array}{c}\text { rs12255372 } \\
\text { rs7903146 } \\
\text { rs7901695 } \\
\text { rs11196205 } \\
\text { rs7895340 }\end{array}$ & 48, 372 & $\mathrm{C}>\mathrm{T}$ & {$[20]$} \\
\hline Northern Sweden & TCF7L2 & 10 & $\begin{array}{c}\text { rs7901695 } \\
\text { rs7903146 } \\
\text { rs12255372 }\end{array}$ & 48,372 & $\mathrm{C}>\mathrm{T}$ & {$[21]$} \\
\hline Europe & TCF7L2 & 10 & $\begin{array}{c}\text { rs7903146 } \\
\text { rs12255372 } \\
\text { rs7901695 }\end{array}$ & 48, 372 & $\mathrm{C}>\mathrm{T}$ & [22] \\
\hline North India & TCF7L2 & 10 & $\begin{array}{l}\text { rs4506565 } \\
\text { rs7903146 }\end{array}$ & 48,372 & $\mathrm{C}>\mathrm{T}$ & {$[23]$} \\
\hline East Asia & TCF7L2 & 10 & $\begin{array}{c}\text { rs7903146 } \\
\text { rs12255372 } \\
\text { rs11196205 } \\
\text { rs290487 }\end{array}$ & 48,372 & $\mathrm{C}>\mathrm{T}$ & [24] \\
\hline United States & TCF7L2 & 10 & $\begin{array}{c}\text { rs12255372 } \\
\text { rs7903146 }\end{array}$ & 48,372 & $\mathrm{C}>\mathrm{T}$ & {$[25]$} \\
\hline Finland & TCF7L2 & 10 & $\begin{array}{c}\text { rs12255372 } \\
\text { rs7903146 }\end{array}$ & 48,372 & $\mathrm{C}>\mathrm{T}$ & {$[26]$} \\
\hline India & TCF7L2 & 10 & $\begin{array}{c}\text { rs7903146 } \\
\text { rs12255372 } \\
\text { rs4506565 }\end{array}$ & 48,372 & $\mathrm{C}>\mathrm{T}$ & [27] \\
\hline
\end{tabular}




\section{Optimization}

PCR components. The optimized PCR volume and concentration for each PCR component is presented in Table 3. Each reaction, with a total volume of $50 \mu \mathrm{L}$, contained 1X 2X Taq master Mix (Vivantis, Malaysia), $10 \mu \mathrm{M}$ each of the forward and reverse primers, 2 ng template DNA.

PCR Conditions. Final PCR conditions showing optimum annealing temperature used for each gene is shown in Table 4. Gradient PCR was done using annealing temperature ranges (in C): 45, 50, 55 up to 60 . The optimized annealing temperature for $K C N Q 1$ is $58.3^{\circ} \mathrm{C}$ and $54.5^{\circ} \mathrm{C}$ for TCF7L2. The initial denaturation was for $3 \mathrm{~min}$, and 35 cycles of: denaturation at $94^{\circ} \mathrm{C}$ for $1 \mathrm{~min}$; annealing at $58.3^{\circ} \mathrm{C}$ for $K C N Q 1$ for $1 \mathrm{~min}$ and at $54.5^{\circ} \mathrm{C}$ for TCF7L2 for $1 \mathrm{~min}$ and; extension at $72^{\circ} \mathrm{C}$ for $1 \mathrm{~min}$. The final elongation was at $72^{\circ} \mathrm{C}$ for 5 min.

Table 3. Optimized volume and final concentration of PCR components

\begin{tabular}{c|c}
\hline PCR Components & Final Conc. \\
\hline 2X Taq master Mix & $1 \mathrm{X}$ \\
\hline Forward Primer & $10 \mu \mathrm{M}$ \\
Reverse Primer & $10 \mu \mathrm{M}$ \\
Template DNA & $2 \mathrm{ng}$ \\
\hline Nuclease -free water & - \\
\hline
\end{tabular}

Table 4. Optimized temperatures, cycles, and duration of PCR conditions

\begin{tabular}{l|c|c}
\hline \multicolumn{1}{c|}{ PCR Conditions } & $\begin{array}{c}\text { Temperature } \\
\text { (9C) }\end{array}$ & Time \\
\hline Initial denaturation & $94^{\circ} \mathrm{C}$ & $3 \mathrm{~min}$ \\
\hline Cycles: 35 & & \\
\hline Denaturation & $94^{\circ} \mathrm{C}$ & $1 \mathrm{~min}$ \\
\hline Annealing & $\begin{array}{c}\mathrm{KCNQ} 1: 58.3^{\circ} \mathrm{C} \\
\mathrm{TCF} 7 \mathrm{~L} 2: 54.5^{\circ} \mathrm{C} \\
\mathrm{DPP} 4:-\end{array}$ & 1 min \\
\hline \multicolumn{1}{c|}{ Elongation } & $72^{\circ} \mathrm{C}$ & $1 \mathrm{~min}$ \\
\hline Final elongation & $72^{\circ} \mathrm{C}$ & $5 \mathrm{~min}$ \\
\hline Infinite hold & $4.0^{\circ} \mathrm{C}$ & $\infty$ \\
\hline
\end{tabular}

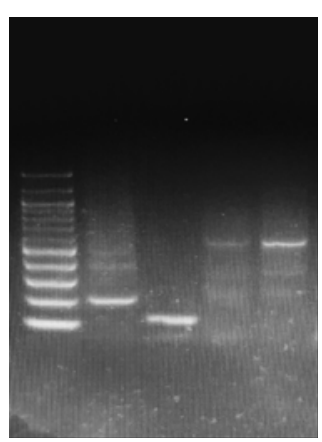

Figure 2. AGE Result Using the Optimized Procedures

\section{Agarose gel electrophoresis of PCR products}

PCR products of target genes sequences in Fig. 2 corresponding to genes KCNQ1 (lane 2), TCF7L2 (lane 3), and DPP4 (lane 4) with 100 bp ladder (lane 1). Sizes in bp for each gene correspond to KCNQ1- 188 bp and for -TCF7L2$133 \mathrm{bp}$. The amplification for DPP4 gene did not initially give a distinct PCR product. The distinct bands were purified, sequenced and verified using BLAST to have targeted the genes specified.

\section{Verification of the sequence results}

Figure 3 shows the sequences of the diabetic and normal samples. For KCNQ1 control, as expected, there was no mutation seen and for the diabetic sample, the mutation was successfully targeted. For TCF7L2 control, the sequence results showed a normal sequence as well. However, for diabetic samples where the mutation must be present, there was no error seen. The DNA sequence results was viewed to BLASTn to confirm the presence of the sequence to the respective genes. Figure 4 shows that the control and diabetic sample sequences results were present to the genes accordingly. It was verified that susceptible genes were targeted using the designed primers and optimized conditions. 


\section{CAA (KCNQ1: Control)}

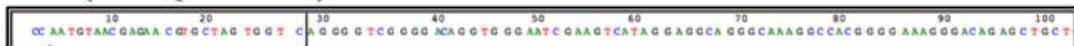

DAA (KCNQ1: Diabetic)

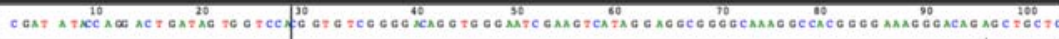

CAB (TCF7L2: Control)

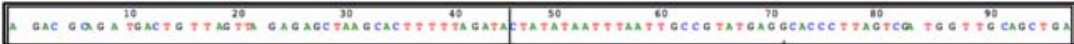

DAB (TCF7L2: Diabetic)

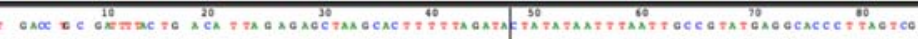

Figure 3. Sequence Results

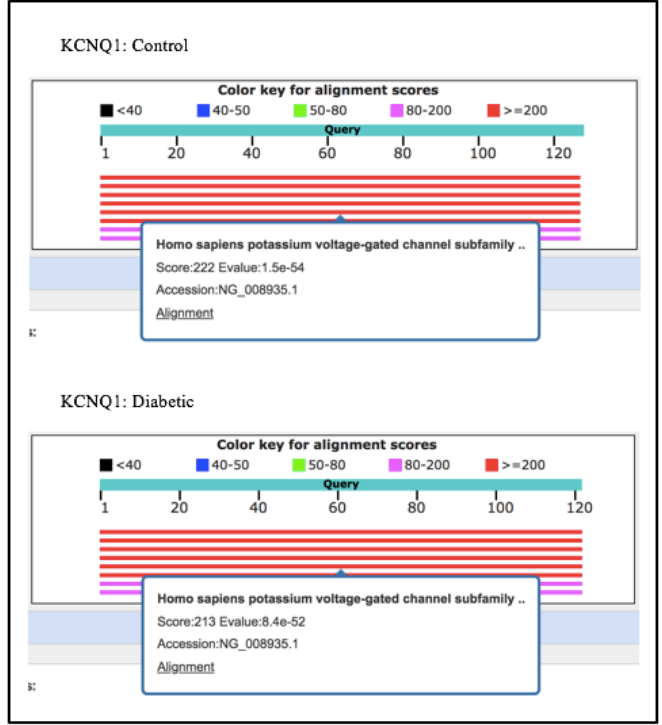

Figure 4. Confirmation of Sequence Results using BLASTn

\section{CONCLUSION}

Using the designed gene specific primers: $\mathrm{F} / \mathrm{R}$ G G C T T T C T C T G C C T C A A A A C C/ ACTAAGGGTGCCTCATACGG for TCF7L2, and for KCNQ1- F/R G T A A G C A G AT G A C A G G G C A G T/ TAAAGGTCCT GACCCCCACC, and the proper PCR conditions, the targets were amplified. The optimized PCR components are: 1X 2X Taq

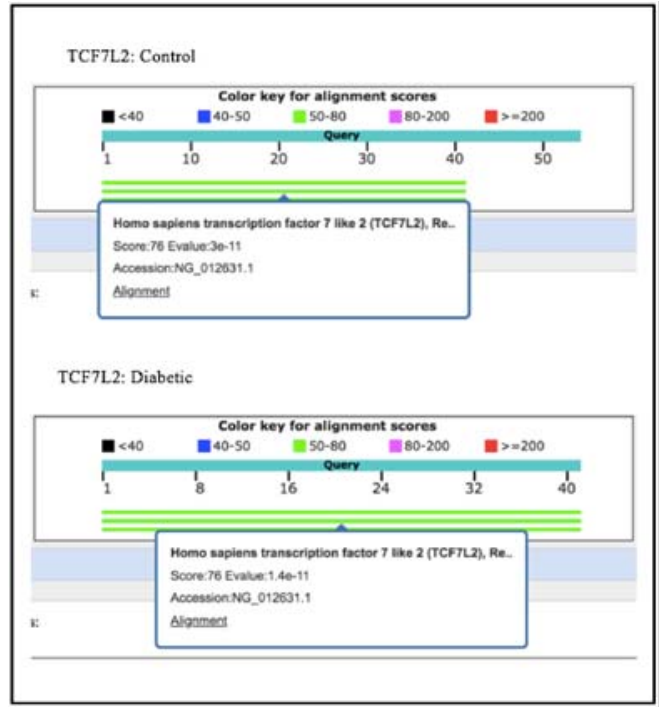

Master Mix, $10 \mu \mathrm{M}$ forward and reverse primers, and 2 ng DNA template. PCR conditions are: initial denaturation, $3 \mathrm{~min}$; 35 cycle of denaturation, $1 \mathrm{~min}$, annealing, $1 \mathrm{~min}$, elongation, $1 \mathrm{~min}$ and; final elongation of $5 \mathrm{~min}$. The annealing temperatures were optimized at $58.3^{\circ} \mathrm{C}$ for $K C N Q 1$ and $54.5^{\circ} \mathrm{C}$ for TCF7L2. These conditions will be used for SNP detection and establish its association with T2DM in Filipino patients. The findings from Sanger sequencing 
were verified using BLAST that showed the alignment with the respective target genes.

\section{ACKNOWLedgment}

The UST Central Laboratory, Molecular Biology Laboratory and the laboratory technicians are gratefully acknowledged. We would also like to acknowledge Prof. Leilani Mercado-Asis,PhD for the inspiration in the initial conception of this study.

\section{REFERENCES}

[1] King $H$, Aubert R, Herman W. Global burden of diabetes: Prevalence, numerical estimates, and projections. Diabetes Care 1998, 21:1414-1431.

[2] Weyer C, Bogardus C, Mott D, Pratley RE. The natural history of insulin secretory dysfunction and insulin resistance in the pathogenesis of type 2 diabetes mellitus. Journal of Clinical Investigation 1999, 104:787-794.

[3] Fridley BL, Patch C. Gene set analysis of SNP data: Benefits, challenges, and future directions. European Journal of Human Genetics 2011,19(8):837-843. DOI:10.1038/ ejhg.2011.57

[4] Hopsu-Havu VK, Glenner GG. A new dipeptide naphthylamidase hydrolyzing glycyl-prolyl-betanaphthylamide. Histochemie 1966, 7(3):197-201. DOI: 10.1007/BF00577838

[5] Röhrborn D. DPP4 in diabetes. Frontiers in Immunology 2015, 6:1-20. DOI: 10.3389/ fimmu.2015.00386

[6] Kroef SV, Noordam R, Deelen J, Akintola AA, Jansen SW, Postmus I, ... Heemst DV. Association between the rs7903146 Polymorphism in the TCF7L2 Gene and Parameters Derived with Continuous Glucose Monitoring in Individuals without Diabetes. PLOS One 2016, 11(2):1-10.

[7] Neyroud N, Richard P, Vignier N, Donger C, Denjoy I, Demay L, Shkolnikova M, Pesce R, Chevalier P, Hainque B, et al. Genomic organization of the KCNQ1 K+ channel gene and identification of C-terminal mutations in the longQT syndrome. Circulation Research 1999, 84:290-297.

[8] Ahmed RH, Huri HZ, Al-Hamodi Z, Salem SD, Alabsi B, Muniandy S. Association of DPP4 gene polymorphisms with type 2 diabetes mellitus in Malaysian subjects. PLOS One 2016, 11(4). DOI: 10.1371/journal.pone.0154369
[9] Xing X, Han Y, Zhou X, Zhang B, Li Y, Wang Z, ...Su L. Association between DPP4 gene polymorphism and serum lipid levels in Chinese type 2 diabetes individuals. Neuropeptides 2016 , 60:1-6. DOI: 10.1016/j.npep.2016.08.005

[10] Hu C, Wang C, Zhang R, Ma X, Wang J, Lu J, ...Jia W. Variations in KCNQ1 are associated with type 2 diabetes and beta cell function in a Chinese population. Diabetologia 2009, 52(7):13221325. DOI: 10.1007/s00125-009-1335-6

[11] Gao K, Wang J, Li L, Zhai Y, Ren Y, You H, ...Wang C. Polymorphisms in Four Genes (KCNQ1 rs151290, KLF14 rs972283, GCKR rs780094 and MTNR1B rs10830963) and Their Correlation with Type 2 Diabetes Mellitus in Han Chinese in Henan Province, China. International Journal of Environmental Research and Public Health 2016, 13(3):260. DOI:10.3390/ ijerph13030260

[12] Saif-Ali R, Ismail IS, Al-Hamodi Z, Al-Mekhla HM, Siang LC, et al. KCNQ1 Haplotypes Associate with Type 2 Diabetes in Malaysian Chinese Subjects. International Journal of Molecular Sciences 2011, 12 (9):5705-5718. <10.3390/ ijms12095705>. <hal-00993503>

[13] Unoki H, Takahashi A, Kawaguchi T, Hara K, Horikoshi M, Andersen G, ...Maeda S. SNPs in KCNQ1 are associated with susceptibility to type 2 diabetes in East Asian and European populations. Nature Genetics 2008, 40(9):10981102. DOI: $10.1038 / n g .208$

[14] Lee YH, Kang ES, Kim SH, Han SJ, Kim CH, Kim $\mathrm{HJ}$, ...Lee HC. Association between polymorphisms in SLC30A8, HHEX, CDKN2A/B, IGF2BP2, FTO, WFS1, CDKAL1, KCNQ1 and type 2 diabetes in the Korean population. Journal of Human Genetics 2008, 53(11-12):991-998. DOI: 10.1007/s10038-008-0341-8

[15] Liu Y, Zhou DZ, Zhang D, Chen Z, Zhao T, Zhang $\mathrm{Z}, \ldots \mathrm{Xu} \mathrm{H}$. Variants in KCNQ1 are associated with susceptibility to type 2 diabetes in the population of mainland China. Diabetologia 2009, 52(7):1315-1321. DOI: 10.1007/s00125-0091375-y

[16] Qi Q, Li H, Loos RJ, Liu C, Wu Y, Hu FB, ... Lin X. Common variants in KCNQ1 are associated with type 2 diabetes and impaired fasting glucose in a Chinese Han population. Human Molecular Genetics 2009, 18(18):3508-3515. DOI: 10.1093/ hmg/ddp294 
[17] Hayashi T, Iwamoto Y, Kaku K, Hirose H, Maeda S. Replication study for the association of TCF7L2 with susceptibility to type 2 diabetes in a Japanese population. Diabetologia 2007, 50(5):980-984. DOI: 10.1007/s00125-007-0618$z$

[18] Chang Y, Chiu KC, Chuang L. Response to Comment on: Chang et al. (2007) Association Study of the Genetic Polymorphisms of the Transcription Factor 7-like 2 (TCF7L2) Gene and Type 2 Diabetes in the Chinese Population: Diabetes 56:2631 2637. Diabetes 2007, 56(12). DOI: $10.2337 / \mathrm{db07-1302}$

[19] Mayans S, Lackovic K, Lindgren P, Ruikka K, Ågren $\AA$, Eliasson M, Holmberg D. TCF7L2 polymorphisms are associated with type 2 diabetes in northern Sweden. European Journal of Human Genetics 2007, 15(3):342-346. DOI: 10.1038/sj.ejhg. 5201773

[20] Guinan KJ. Worldwide distribution of type ii diabetes-associated TCF7L2 SNPs: Evidence for stratification in Europe. Biochemical Genetics 2012, 50(3-4):159-179. DOI: 10.1007/s10528011-9456-2

[21] Gupta V, Khadgawat R, Ng HK, Kumar S, Aggarwal A, Rao VR, Sachdeva MP. A Validation Study of Type 2 Diabetes-related Variants of the TCF7L2, HHEX, KCNJ11, and ADIPOQ Genes in one Endogamous Ethnic Group of North India. Annals of Human Genetics 2010, 74(4):361-368. DOI: 10.1111/j.14691809.2010.00580.x
[22] Luo $Y Y$, Wang HY, Han $X Y$, Ren Q, Wang F, Zhang $X Y, \ldots J i$ LN. Meta-analysis of the association between SNPs in TCF7L2 and type 2 diabetes in East Asian population. Diabetes Research and Clinical Practice 2009, 85(2):139_ 146. DOI: 10.1016/j.diabres.2009.04.024

[23] Sale MM, Smith SG, Mychaleckyj JC, Keene KL, Langefeld CD, Leak TS, ...Freedman, BI. Variants of the transcription factor 7-like 2 (TCF7L2) gene are associated with type 2 diabetes in an AfricanAmerican population enriched for nephropathy. Diabetes 2007, 56(10):2638-2642. DOI: 10.2337/ db07-0012

[24] Scott LJ, Bonnycastle LL, Willer CJ, Sprau AG, Jackson AU, Narisu N, ...Boehnke M. Association of Transcription Factor 7-Like 2 (TCF7L2) Variants With Type 2 Diabetes in a Finnish Sample. Diabetes 2006, 55(9):2649-2653. DOI: 10.2337/db06-0341

[25] Chandak GR, Janipalli CS, Bhaskar S, Kulkarni SR, Mohankrishna P, Hattersley AT, ... Yajnik CS. Common variants in the TCF7L2 gene are strongly associated with type 2 diabetes mellitus in the Indian population. Diabetologia 2007, 50(1):63-67. DOI: 10.1007/s00125-006-0502-2 